\title{
WHAT MACEDONIA? SOME CONSIDERATIONS ON THE CURRENT PERCEPTIONS OF THE NAME DISPUTE AMID FYROM'S EU INTEGRATION BID
}

\author{
Assoc. Prof. Dr. Adrian-Gabriel Corpădean \\ Faculty of European Studies, Babeș-Bolyai University Cluj-Napoca \\ adi_corpadean@yahoo.com
}

DOI:10.24193/OJMNE.2018.26.02

\begin{abstract}
Part of an ampler study dedicated to the European integration prospects of the West Balkans, this study attempts to connect the perceptions of the Macedonian name dispute to the progress of the country in matters of its sinuous accession bid. A brief historical insight into the matter enables one to comprehend the complexity and unusually strong feelings surrounding this unique hurdle in the process of EU enlargement, with inflammatory actions on both sides of the dispute, namely Skopje and Athens, and with protracted efforts of international mediators. While the antiquisation policy pursued by FYROM, which has been a (albeit not the only) bone of contention in the conflict appears to be diminishing, it remains to be seen to what extent perceptions from inside and the vicinity of the interested parties still favour the integration bid and endow it with genuine chances of accomplishment before the feebly-enshrined date of 2025. The study examines the latest developments in the name dispute, with the positions of FYROM, Greek and EU decision-makers, as well as some statistical data underlining the perceptions of affected citizens. Set against the background of the difficulties the candidate country is facing apart from the aforementioned obstacle and the progress made in compliance with the acquis, we bring forth some of the recently-emerged scenarios that are likely to unblock the Macedonian file and, along with it, appease some of the scepticism surrounding the West Balkans' integration bid.
\end{abstract}

Keywords: Macedonia, EU integration, antiquisation, West Balkans, mediation.

\section{Background}

The far-reaching name dispute surrounding the so-called former Yugoslav Republic of Macedonia is undoubtedly a remnant of the early $20^{\text {th }}$ century Balkans turmoil (Herța, 2015, pp. 164-185), a rather peculiar conflict chiefly involving this country and its southern neighbour, Greece, but with much a more intricate background, taking one all the way back 
to the Balkan Wars, only to later cover the Cold War period. In actuality, during the time of the People’s Federal Republic of Yugoslavia and, after 1963, the Socialist Federal Republic of Yugoslavia, the severity of the controversy was somewhat appeased by the inherent division on the continent, albeit protests on the Greek side never ceased even at that time (Rossos, 2013). What becomes of interest to us, as part of this study, is not to perform a history of the dispute, let alone explore its ancient history-inspired validity or linguistic/cultural bases. Instead, we aim to pursue the up-to-date perceptions on the matter under the auspices of FYROM's EU integration bid and to assess the prospects of the issue remaining a paramount hinderance - although far from the only one - in the aforementioned process.

Given its uniqueness in the history of EC/EU accession, which, of course, is no consolation to any of the parties involved, the case study deserves ample exploration and is fertile ground for scenario-building at a time when country denominations are seldom subjected to a process of alteration. Fairly recent precedents do exist, however, which, taken out of their respective geographic, geopolitical and historical contexts, could indicate several approaches to how a name dispute or at least a quest for a country name is likely to be tackled and prompt recognition from the international community may be achieved. A bird's eye view of the map of the world would take a wondering mind from the informally-called "Congo-Brazzaville” to South Sudan, or much closer to the case at hand, with names such as the Republic of Moldova, all of which could spark a note of controversy connected to the nottoo-distant past.

Having set the objective of examining the nature of the FYROM file, it becomes apparent that our study may in no way stake a claim to be comprehensive with respect to the Macedonian terminological dispute, but rather to examine some of its possible resolutions, from the standpoint of the broader file of the integration of the West Balkans into the European Union, which is of interest to us. That said, we acknowledge the fact that the controversy extends beyond, on the one hand, the EU integration endeavour, given the fact that the NATO membership of the country is also put on hold for similar reasons, and on the other hand, since Greece is not the only member state of the Union to have formulated objections to the integration bid (even though it has been by far the most vocal), with Bulgaria expressing concern over the situation of its minority living on the territory of 
FYROM (Katsikas, 2012, pp. 74-78). Nevertheless, we acknowledge that, while both NATO accession and EU negotiations are of importance to the country and broader area, we shall solely focus on the impact of the case on the latter file, whose intricacies are unquestionably greater than the much more straightforward former endeavour.

In order to underline our unbiased view on the thorny subject and to avoid complication over the nomenclature used, we shall opt for the acronym FYROM when neutrally addressing the country, with the full spelling of the word "former" in minuscule, in keeping with the United Nations' Security Council Resolution 817 of 7 April 1993, denoting a descriptive term, rather than an official name of a state (UN, 1993).

One more significant mention which we deem necessary for a proper introduction to the matter of perception surrounding the name dispute is the fact that, complementarily to it, FYROM has been involved, after gaining its independence in 1991, in a broader quest for a renewed national identity, one which would engender prestige and the kind of symbolism that brings a nation closer to its homeland. The process took the form of or became draped in nationalism, chiefly after the proclamation of independence, amid the ethnic and linguistic complications arising at the time, and devolved into what specialised literature commonly refers to as "antiquisation” (Peshkopia, 2014, pp. 183-186). A process of questionable archaeological accuracy and with perilous consequences on the ethnic stance of some of the people living within the country's borders, such as Albanians, but also Macedonians themselves to some extent, it was notably pursued by the governing Internal Macedonian Revolutionary Organization - Democratic Party for Macedonian National Unity, between 2006 and 2016. So what is the decade-long process about and why did it spark so much controversy? The adornment of cities across the country, with the capital, Skopje, in the limelight, with statues and representations of Alexander the Great and Philip II of Macedon, and the baptising of landmarks, from airports to motorways, with such names, lies at the core of the politicised process. This, of course, only amplified the dérapage of the country from its Euro-Atlantic path, drawing stark criticism from Greece, but frowned upon by more and quickly turning into a focal point of the international community. To make matters worse, or at least more tortuous, under the impetus of the powerful FYROM diaspora, the occasional unrealistic leitmotiv of Greater Macedonia springs into public debate, which is not unique in 
the Balkan scenery, but does serve as a damaging complement to the already spiky situation (Ahrens, 2007, pp. 382-386).

Whilst formulating its objections on the historical accuracy of such claims as the aforementioned ones, usually grouped around the “antiquisation” concept, Greece has also turned to the classic argument of possible territorial claims made by a country bearing the same name as its northern province, a subject which has been put forward on occasions by FYROM nationalists. We concede that the logical validity of the assumption stands, as does its historical analogies that have occasionally been brought forth by Greek decision-makers, although we cast doubt on the likelihood of any actual change that may be triggered in foreseeable times by the action itself. Regardless, institutionally speaking, this objection has led to numerous setbacks, delays and failures in the integration and modernisation endeavours of FYROM, as soon as it became an independent nation. If a UN membership compromise was brokered in 1993 (Danforth, 1997, pp. 150-151), in an unprecedented move surrounded by uncertainty over the future, a permanent solution appears to be the only clearcut guarantee that the country would be allowed to move forward in the two major national projects pending, i.e. NATO and EU membership. Negotiations under UN auspices have been pursued since 1994, with US senior diplomat Matthew Nimetz dedicating more than two decades of his career to this unique undertaking, in a truly spectacular case worthy of a thorough biographical insight, especially if a happy ending is eventually brokered (Peshkopia, 2014, pp. 195-205).

Progress at the core of the issue was first achieved in 1995, with the Interim Accord brokered between Greece and FYROM, allowing the latter to broaden its international prospects (by joining the Council of Europe, for instance), on condition that some symbols and constitutional provisions be changed by FYROM - such as the discontinuation of the use of the Vergina Sun symbol on its national flag (Papavizas, 2006, pp. 224-225). That said, despite economic ties running smoothly with both Greece and other countries on the continent, most of which have shown no sign of reluctance to adopt and use the name Republic of Macedonia, it is evident that neither NATO nor EU membership can advance with Greece's veto power hanging over the already complicated files. On the other hand, FYROM nationals have also been exhibiting particular sensitivity to the matter, reacting negatively to attempts to be referred to as "Skopians" or "Macedonian Slavs" (Roisman and 
Worthington, 2010, p. 573), which only strengthens the idea that symbols remain paramount from the national standpoint in this day and age and convey exceptionally strong feelings and cohesive factors.

A major institutional setback was met during the NATO Bucharest summit of 2008, when FYROM was not invited to join the organisation, unlike Albania and Croatia, with the name dispute cited as the principal hinderance and with certain risks to the ever more challenging geopolitics of the region (Aybet and Moore, 2010, pp. 186-187). In a predictable outcome, the FYROM government decided to initiate proceedings against Greece before the International Court of Justice for the resolution of the name dispute, whose verdict, although favourable to the former, failed to result in any imposition on Greece to lift its veto (ICJ, 2011). Thus, the severity of the case emerges and the spread of its implications begin to exhibit how much damage FYROM is likely to sustain in the absence of a definitive resolution.

\section{Impact on FYROM's EU integration}

The relations between FYROM and the European Union were initiated not long after the country's successful independence bid, while in 1995, the two parties engaged in formal diplomatic ties, in preparation for the Cooperation Agreement. This calendar (Government of the Republic of Macedonia, 2018) indicates the drive of the former communist state to detach from the past and pave the way for a pro-western solution, not unlike most of its former fellow-regions within Yugoslavia. After the coming into force of the Cooperation Agreement in 1996, the driving force behind FYROM's EU endeavour became the need to sign a Stabilisation and Association Agreement, which was accomplished on 9 April 2001, in Luxembourg, and entered into force in 2004.

The internal situation of the country was complex, given the large number of Albanian nationals that had sought refuge there amid the Kosovo War, leading to a destabilisation of the political context and more. The presence of the Albanians' National Liberation Army on FYROM's territory and its hostile actions in 2001 saw Macedonia in the midst of a NATO intervention, aimed at stabilising the dangerous internal situation. This was followed by the signing of the Ohrid Agreement with the ANLA, which eventually led to a normalisation of the situation within its borders (Ohrid, 2001). The favourable outcome then 
enabled the EU to take over the peacekeeping duties from NATO and engage more actively with the Government in Skopje.

At the Thessaloniki Summit in 2003, FYROM had been declared a potential candidate to EU membership, along with the broader region of the West Balkans, which prompted an application from Skopje in this respect, in March 2004, days before the Stabilisation and Association Agreement between the parties came into force. A National Strategy for European Integration was adopted by the Government in Skopje, setting out the priorities and strategies meant to accompany the country throughout its foreseeably protracted negotiation process. On 9 November 2005, the European Commission, under the impetus of the Commissioner for Enlargement, Olli Rehn, issued a formal recommendation for the country to be granted candidate status, which was subsequently approved by the European Council. The timeline continues with December 2009, when the visa liberalization regime was instilled and FYROM appeared to be on track, following a comparable calendar to other neighbouring countries aspiring to join the Union, such as Montenegro and Serbia (Delegation of the European Union to the Former Yugoslav Republic of Macedonia, 2016).

From a financial standpoint, FYROM was eligible to benefit from pre-accession funds on the part of the EU, in spite of the name dispute, starting with PHARE and, as of 2007, under the auspices of the Instrument for Pre-accession Assistance, given the signing of the Framework Agreement with the EU. Between 2007 and 2013, 622 million euros were allocated to FYROM by the EU, while in the current multiannual framework of 2014-2020, the country has been granted 664.2 million euros to conduct its internal reforms, in keeping with its integration requirements, following the known set of priorities set for the entire West Balkans region (Idem).

It is in December 2009 that the green light was received by FYROM from the European Commission to start formal negotiations with the EU, and with the support of the European Parliament, but this failed to materialise itself, chiefly on the grounds of the name dispute with Greece. Whilst the High-Level Accession Dialogue between the European Commission and Skopje was initiated in 2012, the aforementioned hurdle prevented FYROM from attaining any progress in opening negotiation chapters. To make matters worse, in May 2015, a major political crisis erupted around the conflict between then-Prime-Minister Nikola Gruevski, of the Internal Macedonian Revolutionary Organization - Democratic Party for 
Macedonian National Unity, and opposition leader Zoran Zaev, from the Social Democratic Union. The involvement of the EU in the resolution of the crisis, which included accusations of illegal wiretapping and even the alleged obstruction of a murder investigation by the Government, was prompt and led to the signing of the Pržino Agreement, in July 2015 (Euractiv, 2015). It becomes apparent that the EU has indeed assumed a stabilising role within the country, whose legitimacy partly stems from the decidedly pro-integration path adopted by Skopje. In fact, according to the European Commission's progress report on FYROM for 2018, the country has returned to a state of political stability (FYROM Report, 2018), notably after the election of Zoran Zaev as Prime-Minister, with a pro-EU and proNATO message, albeit both endeavours remain blocked by the name dispute.

\section{Prospects amid the latest developments}

Facing a categorical veto on the part of Greece and with neighbour Bulgaria hinting at the possibility to voice opposition to membership as well, FYROM appears to have picked up the pace of its actions meant to overcome this rather peculiar battle, but with major consequences on its security and prosperity. Despite the uncertainty that still hovers over the file, PM Zaev voiced the apparently positive developments in the dispute, in an interview with Reuters from 27 February 2018: “The suggestions are Republic of North Macedonia, Republic of Upper Macedonia, Republic of Vardar Macedonia and Republic of Macedonia (Skopje)” (Jones, 2018). His message echoes some of the geographically-based denominations that have been put forward on various occasions, as potential solutions to the disagreement with Greece. Indeed, the reaction from the Greek Government hits an unusually optimistic note, with Foreign Minister Nikos Kotzias declaring in a news conference held in Skopje, on 23 March 2008, that: “Today, we made steps to solve the problems we inherited” and "We have agreed in great degree what we want for the future" (RFE/RL, 2018).

Moreover, it is not to be left out that the most important political parties in FYROM have stood for election on a pro-EU and mostly pro-NATO agenda. The Internal Macedonian Revolutionary Organization - Democratic Party for Macedonian National Unity has been affiliated, as an associate member, with the European People’s Party since 2007 (Jansen, Steven Van Hecke, 2011, p. 79), while the Social Democratic Union of Macedonia is an 
associate of the Party of European Socialists*. Also, the largest Albanian party in FYROM, the Democratic Union for Integration, openly embraces a pro-EU agenda, ${ }^{\dagger}$ which is quite significant because the Albanian minority comprises approximately a quarter of FYROM's population (Cole, 2011, p. 8).

With respect to the public opinion, a survey published on 17 February 2017 by the Macedonian Information Agency and led by the Institute for Democracy “Societas Civilis", together with the Konrad Adenauer Foundation, shows that 77\% of FYROM's citizens are in favour of European integration. Ivan Damjanovski, of "Societas Civilis", explains that the figure would rise to $90 \%$ in the absence of the name dispute. The same study indicates that $26 \%$ of citizens believe the EU is the country's most powerful foreign ally, closely followed by Russia (25\%) and the USA (17,5\%), still indicating a net pro-western tilt (Macedonian Information Agency, 2017).

The EU's Commissioner for Enlargement, Johannes Kahn, has recently declared himself to be "very confident” that the name dispute will be settled before July 2018. On 16 February 2018, he explained that he was "optimistic that in the next two weeks we will have a solution. At least a solution that will open the way for the beginning of accession talks with FYROM”, which - although did not occur - clearly indicated the readiness of the EU's executive to initiate formal negotiations, in which case the name dispute indeed remains the last (and perhaps it has always been the sole) obstacle. Nevertheless, this fairly optimistic statement prompted less than amiable reactions on the part of Athens and, to a lesser extent, Skopje. While the Greek Ministry of Foreign Affairs qualified the message as "unfortunate" and painting a "wrong picture of the negotiations", FYROM Prime-Minister Zaev treated it with gentler but no less discrediting words: "I would love it a lot, but I think it is not possible” (Euractiv, 2018).

In the meantime, the Commission does not fail to take advantage of any means at its disposal to reassert its commitment to starting accession talks with both FYROM and Albania, as underlined by HR Federica Mogherini on 18 April 2018, on a visit to Tirana

\footnotetext{
* The pro-EU agenda of the Party also emerges from the strategic documents published on its official platform: http://www.sdsm.org.mk.

† Same observation as above. See website: http://bdi.mk/en/index.php.
} 
(Grobe, 2018). The predictable announcement reflected the internal decision of the European Commission to give this needed impetus to the two countries, which are supposed to join Montenegro and Serbia in the customary negotiation of chapters, with Kosovo remaining on the side-lines pending full recognition from all member states. However, the European Council in June is expected to have the last word on the matter which, in the absence of concrete resolution signals from Athens, is bound to once again slide into the maze of postponement.

\section{Bibliography:}

- $\quad$ AHRENS, Geert-Hinrich, Diplomacy on the Edge: Containment of Ethnic Conflict and the Minorities Working Group of the Conferences on Yugoslavia, Woodrow Wilson Center Press, 2007.

- $\quad$ AYBET, Gülnur; MOORE, Rebecca R., NATO in Search of a Vision, Georgetown University Press, 2010.

- $\quad$ COLE, Jeffrey E., Ethnic Groups of Europe: an Encyclopedia, ABC-CLIO, 2011.

- DANFORTH, Loring M., The Macedonian Conflict: Ethnic Nationalism in a Transnational World, Princeton University Press, 1997.

- $\quad$ GROBE, Stefan, "FYROM, Albania moving closer to EU accession talks”, Euronews, 18 April 2018, http://www.euronews.com/2018/04/18/fyrom-albania-moving-closer-to-euaccession-talks, last access: 22 May 2018.

- $\quad$ HERT,A, Laura M., "The Violent Conflicts in Former Yugoslavia and the Vacillations of The West: Transatlantic Discourse Constructions of the Yugoslav Wars”, On-line Journal Modelling the New Europe, Issue no. 17, December 2015.

- JANSEN, Thomas; VAN HECKE, Steven, At Europe's Service: the Origins and Evolution of the European People's Party, Springer, 2011.

- JONES, Marc, "Macedonia has four options to resolve name dispute with Greece: PM”, Reuters, 27 February 2018, https://www.reuters.com/article/us-macedoniagreece/macedonia-has-four-options-to-resolve-name-dispute-with-greece-pmidUSKCN1GB1WA, last access: 30 April 2018. 
- $\quad$ KATSIKAS, Stefanos, Negotiating Diplomacy in the New Europe: Foreign Policy in Post-Communist Bulgaria, I.B.Tauris, 2012.

- $\quad$ PAPAVIZAS, George C., Claiming Macedonia: the Struggle for the Heritage, Territory and Name of the Historic Hellenic Land, 1862-2004, McFarland, 2006.

- $\quad$ PESHKOPIA, Ridvan, Conditioning Democratization: Institutional Reforms and EU Membership Conditionality in Albania and Macedonia, Anthem Press, 2014.

- $\quad$ ROISMAN, Joseph; Worthington, Ian, A Companion to Ancient Macedonia, John Wiley \& Sons, 2010.

- $\quad$ ROSSOS, Andrew, Macedonia and the Macedonians: a History, Hoover Press, 2013.

- Delegation of the European Union to the former Yugoslav Republic of Macedonia, The Former Yugoslav Republic of Macedonia and the EU, 12 May 2016, https://eeas.europa.eu/delegations/former-yugoslav-republic-macedonia/1457/formeryugoslav-republic-macedonia-and-eu_en, last access: 22 May 2018.

- $\quad$ Framework Agreement Concluded at Ohrid, Macedonia, signed at Skopje, Macedonia on 13 August 2011, OSCE Archives, https://www.osce.org/skopje/100622?download=true, last access: 22 May 2018.

- Government of the Republic of Macedonia, Secretariat for European Affairs, Timeline of the relations with EU, 2008, http://www.sep.gov.mk/en/content/?id=8\#.WwSDpEiFNPY, last access: 22 May 2018.

- International Court of Justice, Press Release No. 2011/37, 5 December 2011, http://www.icj-cij.org/files/case-related/142/16841.pdf, last access: 22 May 2018.

- The former Yugoslav Republic of Macedonia 2018 Report, Commission Staff Working Document, Strasbourg, 17.4.2018 SWD(2018) 154 final, https://ec.europa.eu/neighbourhood-enlargement/sites/near/files/20180417-the-formeryugoslav-republic-of-macedonia-report.pdf, last access: 30 April 2018.

- United Nations' Security Council Resolution 817 of 7 April 1993, S/RES/817, https://undocs.org/S/RES/817(1993), last access: 22 May 2018.

- “Commission hammers out Macedonia compromise”, Euractiv, 16 July 2015, https://www.euractiv.com/section/enlargement/news/commission-hammers-out-macedoniacompromise/, last access: 22 May 2018. 
- “Greek, Macedonian Officials See Progress in Name Dispute”, Radio Free Europe / Radio Liberty, 23 March 2018, https:/www.rferl.org/a/greece-macedonia-name-disputeskopje-negotiations/29120384.html, last access: 30 April 2018.

- “Hahn 'confident’ Macedonia name row settled by July”, Euractiv, 16 February 2018, https://www.euractiv.com/section/enlargement/news/hahn-confident-macedonia-name-rowsettled-by-july/, last access: 22 May 2018.

- $\quad$ "Public support for EU membership in Macedonia drops to 77\%: poll”, Macedonian $\begin{array}{lllll}\text { Information } & \text { Agency, } & 17 & \text { February }\end{array}$ https://www.mia.mk/en/Inside/RenderSingleNews/289/133575238, last access: 30 April 2018. 